\title{
PECULARITIES OF STUDENTS' ATTITUDE TOWARDS THE STUDIES AND THE PHYSICAL EDUCATION TEACHER IN THE ASPECT OF GENDER
}

\author{
Jurgita Čepelioniené $\dot{1}^{1,2}$, Vida Ivaškiené ${ }^{2}$ \\ Mykolas Romeris University ${ }^{1}$, Lithuanian Sports University ${ }^{2}$
}

\begin{abstract}
The most important factor of physical education at the university level is the teacher hence it is his qualifications, educational mastery on which depends his ability to create a favorable learning atmosphere with the respect to the educational and emotional aspects. The relationship between the physical education specialist and students, the content of the practical lessons, methods and theoretical lectures influence the formation of students' attitude towards physical activities and the development of the practical acts The purpose of the research is to set student's attitude towards the studies and physical education teacher relying on the gender aspect. Empirical research was conducted in the spring semester of year 2009. The 491 students were involved in this study (362 female and 129 male).
\end{abstract}

Keywords: gender, physical education, students, studies, teacher, university.

\section{Introduction}

Contemporary academic youth views the world which is full of changes and the tempo of these changes is dramatic. It is not that easy to orientate in everchanging existential environment. It is necessary to understand and to find out how to acquire a professional competence, create the system of values and to achieve high culture level without damaging psychological and physical health in such circumstances (Dadelo et al., 2008; Pranckevičienè et al., 2008; Palionytė and Pruskus, 2012; Zulumskytė and Gelminaitė, 2011; Tamošauskas, 2012; Bobrova, 2012).

The primary role of the universities and educational system of Lithuania is to raise an individual who is open to the culture and democracy. Physical education as a part of common culture cannot stay away from these problems solution. Assisting a human being in existence physical education also helps to implement the vocation. It covers various levels of individual's functioning - starting with the physical and finishing with the spiritual. Well-developed physical culture could help to adapt to existing culture, pick up and stick to the basis of such values as "you and the others". The way an individual manages to understand and adapt to the particular volatile existential environment is the way of free, culturally-equipped individual's formation (Tamošauskas, 2012).

The most important factor of physical education at the university level is the teacher hence it is his qualifications, educational mastery on which depends his ability to create a favourable learning atmosphere with the respect to the educational and emotional aspects (Tamošauskas, 2007; Poteliūnienè, 2010).

The object of teacher's performance is a student who manages to take subjective position and become an active participant of the educational process with his own purposes, believes, motives, logic behaviour and whose role is to acquire 
the given information during the learning process (Adamoniene et al., 2001, quoted from Mackelo and Drūteikienè, 2010).

The relationship between the physical education specialist and students, the content of the practical lessons, methods and theoretical lectures influence the formation of students' attitude towards physical activities and the development of the practical acts (Tamošauskas et al., 2004, quoted from Dadelo et al., 2008, Трухачёв et al., 2014).

However, there is a lack of works which would examine the problematic areas related to the students' attitude towards studies and physical education teachers. Students' attitude towards the quality of the studies had been analyzed (Barkauskaitė and Nedzinskaite, 2010; Baranauskienè et al., 2011), students' opinion about the aspects of quality of evaluation at university level and the peculiarities of students' academic results evaluation was presented (Sirtautiené, 2006; Morkūnienè and Jucevičienè, 2010) and students' attitude towards teacher's educational competence was researched (Raišienè, 2004). This encouraged planning the research with the help of which the differential features would be brought into light and it should help better organize and optimize physical education lessons, the nature of physical education teachers' work and students' learning.

The research relies on the following theoretical provisions:

1. The professionalism of the physical education teacher and the physical education life-long learning (Corbin and Strauss, 2007) conceptual provisions.

2. The Humanistic education philosophy approach about individual's wholeness, indivisibility. Relying on the individualistic holistic principle, there must manifest spiritual, social and physical power harmony instead of the separate physical power education signs during the physical education (Bitinas, 2000).

3. The Democratic educational theory. It points to democratic interaction between the educator and the learner: mutual activity, equivalent communication and cooperation (Jackūnas, 1997).

The purpose of the research is to set student's attitude towards the studies and physical education teacher relying on the gender aspect.

The objectives of the research:

1. Analyze students' attitude towards studies.

2. Ascertain students' opinion about the most liked features of the physical education teachers.

3. Ascertain students' opinion about the most disliked features of the physical education teachers.

Organization of the research and research methodology

Research methods: 1. Questionnaire. 2. Statistical analysis.

The research relied on the written survey method (questionnaire) in order to distinguish and evaluate the research shifting. Students' attitude towards studies 
and the teacher of physical education was established with the help of the provided question list. Students were asked about their educational achievements, academic university requirements and physical education classes. Empirical research was conducted in the spring semester of year 2009. Participants of the research were chosen in a convenient sampling way, the questionnaire was provided with respect to the study timetable and possibilities provided by the administration. The scope of the research was compiled of the representative students group which was chosen with the respect to convenient sampling way from the universities. 491 first year student took part in the research (362 females and 129 males). The data was analyzed with the help of the statistical data software package SPSS 13.0 for Windows. In order to examine different groups' percentage the percent evaluation of the different groups' statistical differences was tested with the help of chi-square test $\left(\chi^{2}\right)$. Differences with the probability less than 0.05 were considered as statistically reliable.

\section{Results}

Analyzing the study results it came clear that the majority of students evaluate academic university requirements fairly well (respectively $75.8 \%$ of males and $76.7 \%$ of females; $p=0.235$ ) (Table 1$)$.

Table 1

Response to the question "How a student should evaluate academic university requirements?" distribution of relative frequency of occurrence (\%)

\begin{tabular}{|l|c|c|c|}
\hline \multirow{2}{*}{\multicolumn{1}{|c|}{ Statement }} & \multicolumn{2}{|c|}{ Research } & \multirow{2}{*}{$\chi^{2}$ and $\mathrm{p}$ values } \\
\cline { 2 - 3 } & Male & Female & \\
\hline Very low & 0.8 & 0.3 & $\chi^{2}(3)=4.25, \mathrm{p}=0.235$ \\
\hline Sufficiently low & 11.3 & 6.7 & $\chi^{2}(3)=4.25, \mathrm{p}=0.235$ \\
\hline High enough & 75.8 & 76.7 & $\chi^{2}(3)=4.25, \mathrm{p}=0.235$ \\
\hline Very high & 12.1 & 16.4 & $\chi^{2}(3)=4.25, \mathrm{p}=0.235$ \\
\hline
\end{tabular}

It is established that studies at university are very significant for the students (45.3\% males and $58.0 \%$ females) or fairly significant (respectively $47.7 \%$ and $41.1 \%$ respondents) (Fig. 1). For the females studies are more important than for males $(\mathrm{p}=0.001)$. 


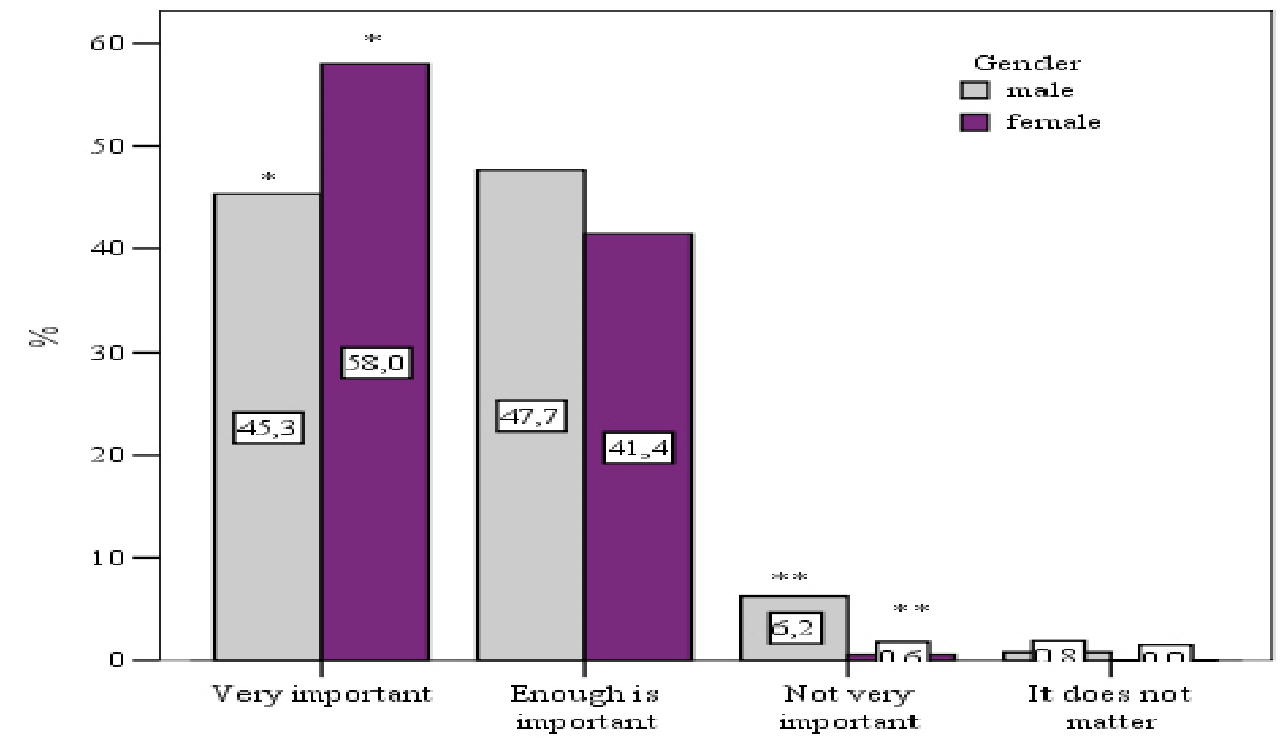

Figure 1 Response to the question "Is it important for you to study at university?" distribution $(\%),\left(\chi^{2}(3)=21.50, p=0.001\right)$

Approximately half of the students (44.1\% of males and $57.5 \%$ of females) believe that their academic achievements are the same as the achievements of the others, accordingly $40.9 \%$ and $30.4 \%$ of respondents think that their academic results are better than their peers (Fig. 2). For the females academic achievements are more important than for males $(\mathrm{p}=0.039)$.

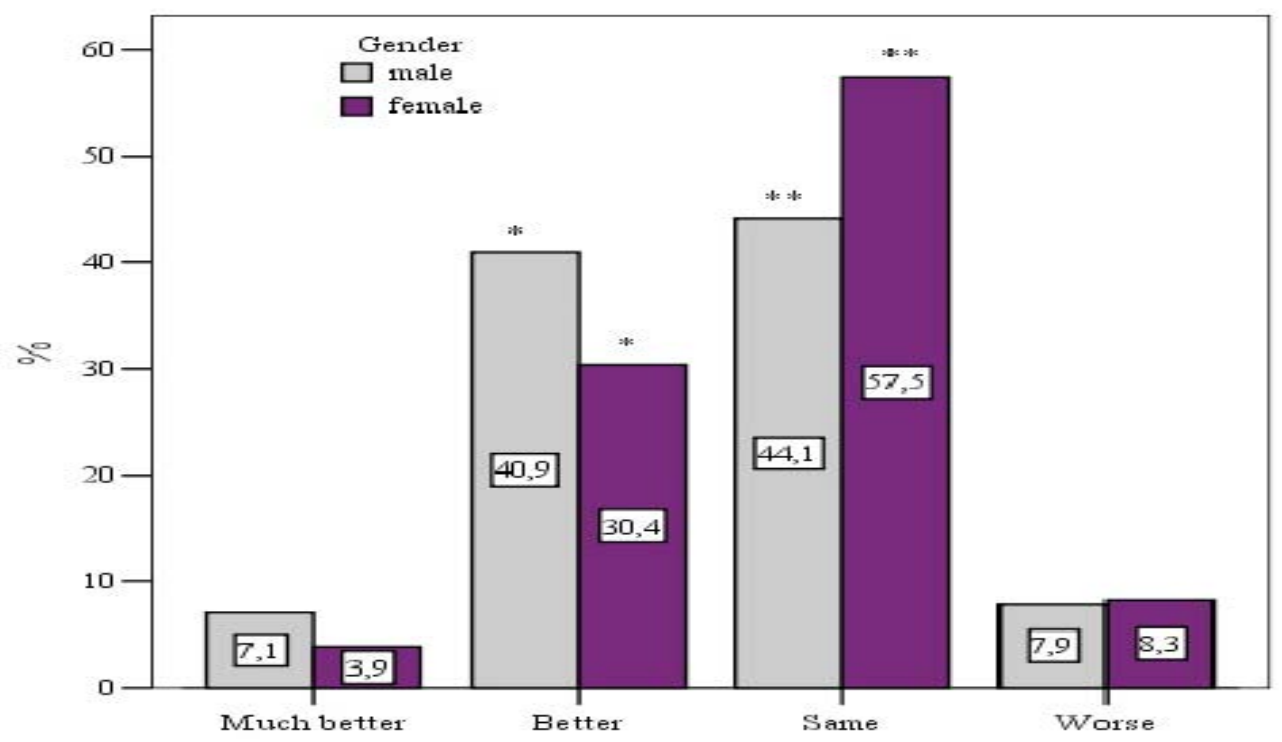

Figure 2 Response to the question "How do you evaluate your academic results in comparison with your peers average?" distribution $(\%),\left(\chi^{2}(3)=8.365, p=0.039\right)$

During the analysis of the students' answers about the most liked traits of the physical education teachers it came clear that the answers between the females and males to all the statements in the questionnaire differ dramatically $(p=0.05)$ (an exception - there is no significant difference set about the statement related to the communication with the group) (Table 2). 
Proceeding of the International Scientifical Conference May $23^{\text {th }}-24^{\text {th }}, 2014$

Volume III

Table 2

Response to the question "What traits of the physical education teacher do you
appreciate the most?" distribution of relative frequency of occurrence $(\%)$

\begin{tabular}{|c|c|c|c|c|c|c|c|}
\hline Statement & Research & $\begin{array}{c}\text { I would } \\
\text { certainly } \\
\text { agree }\end{array}$ & I agree & $\begin{array}{l}\text { Neither } \\
\text { good } \\
\text { nor bad }\end{array}$ & $\begin{array}{c}\text { I do } \\
\text { not } \\
\text { agree }\end{array}$ & $\begin{array}{l}\text { Definite } \\
\text { ly don't } \\
\text { agree }\end{array}$ & $\begin{array}{c}\chi^{2} \text { and } p \\
\text { values }\end{array}$ \\
\hline \multirow{2}{*}{$\begin{array}{l}\text { Good physical } \\
\text { appearance }\end{array}$} & Male & 18.1 & 36.2 & 32.3 & 9.4 & 3.9 & \multirow{2}{*}{$\begin{array}{l}\chi^{2}(4)= \\
43.97 \\
p= \\
0.001\end{array}$} \\
\hline & Female & 22.6 & 55.0 & 20.9 & 1.4 & 0 & \\
\hline \multirow[t]{2}{*}{ Friendly } & Male & 29.7 & 55.5 & 10.9 & 0.8 & 3.1 & \multirow{2}{*}{$\begin{array}{l}\chi^{2}(4)= \\
11.64 \\
p= \\
0.020\end{array}$} \\
\hline & Female & 31.1 & 55.8 & 11.7 & 1.4 & 0 & \\
\hline \multirow[t]{2}{*}{ Knowledgeable } & Male & 36.4 & 46.5 & 12.4 & 0 & 4.7 & \multirow{2}{*}{$\begin{array}{l}\chi^{2}(3)= \\
21.90 \\
p= \\
0.001\end{array}$} \\
\hline & Female & 38.6 & 54.7 & 6.7 & 0 & 0 & \\
\hline \multirow[t]{2}{*}{ Calm } & Male & 22.8 & 47.2 & 22.8 & 3.9 & 3.1 & \multirow{2}{*}{$\begin{array}{l}\chi^{2}(4)= \\
17.18 \\
p= \\
0.002\end{array}$} \\
\hline & Female & 16.4 & 45.1 & 33.4 & 5.0 & 0 & \\
\hline \multirow{2}{*}{$\begin{array}{l}\text { Communicates } \\
\text { with a group }\end{array}$} & Male & 28.7 & 42.6 & 21.7 & 3.1 & 3.9 & \multirow{2}{*}{$\begin{array}{l}\chi^{2}(4)= \\
9.20 \\
p= \\
0.056\end{array}$} \\
\hline & Female & 28.1 & 46.8 & 18.9 & 5.6 & 0.6 & \\
\hline \multirow{2}{*}{$\begin{array}{l}\text { Has a sense of } \\
\text { humor }\end{array}$} & Male & 30.5 & 43.0 & 16.4 & 3.9 & 6.3 & \multirow{2}{*}{$\begin{array}{l}\chi^{2}(4)= \\
24.17 \\
p= \\
0.001\end{array}$} \\
\hline & Female & 33.6 & 43.6 & 20.3 & 2.5 & 0 & \\
\hline \multirow{2}{*}{$\begin{array}{l}\text { Interested in } \\
\text { each student }\end{array}$} & Male & 17.1 & 41.1 & 28.7 & 6.2 & 7.0 & \multirow{2}{*}{$\begin{array}{l}\chi^{2}(4)= \\
26.09 \\
p= \\
0.001\end{array}$} \\
\hline & Female & 14.8 & 26.2 & 39.6 & 17.5 & 1.9 & \\
\hline \multirow{2}{*}{$\begin{array}{l}\text { With him easy } \\
\text { to communicate }\end{array}$} & Male & 28.7 & 40.3 & 21.7 & 6.2 & 3.1 & \multirow{2}{*}{$\begin{array}{l}\chi^{2}(4)= \\
14.05 \\
p= \\
0.007\end{array}$} \\
\hline & Female & 26.2 & 43.2 & 27.0 & 3.6 & 0 & \\
\hline \multirow[t]{2}{*}{ Creative } & Male & 21.7 & 30.2 & 39.5 & 3.9 & 4.7 & \multirow{2}{*}{$\begin{array}{l}\chi^{2}(4)= \\
20.30 \\
p= \\
0.001\end{array}$} \\
\hline & Female & 16.7 & 30.1 & 46.5 & 6.7 & 0 & \\
\hline \multirow{2}{*}{$\begin{array}{l}\text { Apply } \\
\text { innovation }\end{array}$} & Male & 21.9 & 32.8 & 32.8 & 6.3 & 6.3 & \multirow{2}{*}{$\begin{array}{l}\chi^{2}(4)= \\
13.98 \\
p= \\
0.001\end{array}$} \\
\hline & Female & 21.3 & 33.9 & 34.7 & 10.1 & 0 & \\
\hline \multirow{2}{*}{$\begin{array}{l}\text { Take into } \\
\text { account the } \\
\text { opinion of } \\
\text { students when } \\
\text { allocating tasks }\end{array}$} & Male & 26.6 & 38.7 & 28.2 & 2.4 & 4.0 & \multirow{2}{*}{$\begin{array}{l}\chi^{2}(4)= \\
11.24 \\
p= \\
0.024\end{array}$} \\
\hline & Female & 22.3 & 34.9 & 32.7 & 8.9 & 1.1 & \\
\hline
\end{tabular}


The analysis of the research answers stressed the fact that students mostly appreciate the friendliness of the physical education teacher: such answers as "completely agree" and "agree" were marked by $85.2 \%$ of males and $86.9 \%$ of females. Also, students appreciate when the teacher knows his subject well (answers "agree completely and agree were chosen by $82.9 \%$ of males and $93.3 \%$ of females), good sense of humour (relatively $73.5 \%$ of males and $77.2 \%$ of females). Students also like teachers of physical education who are in a good shape; it is much more significant for the females rather than for males $(\mathrm{p}=$ $0.001)$.

The research data related to the analysis of the traits the physical education teacher has to possess had shown that it is quite important for the students to easily communicate with the teacher, that the teacher is calm and relies on the respondents opinion while distributing the tasks.

While analyzing the research data about the lecturer's traits which are disliked by the students (Fig. 3) it came clear that both males and females do not like the teachers who require the fulfilment of the standards (answers "completely agree" and "agree" were chosen by 9.3 and $27.9 \%$ of males and 9.4 and $19.1 \%$ of females; $p=0.037$ ). Females do not like more than males.

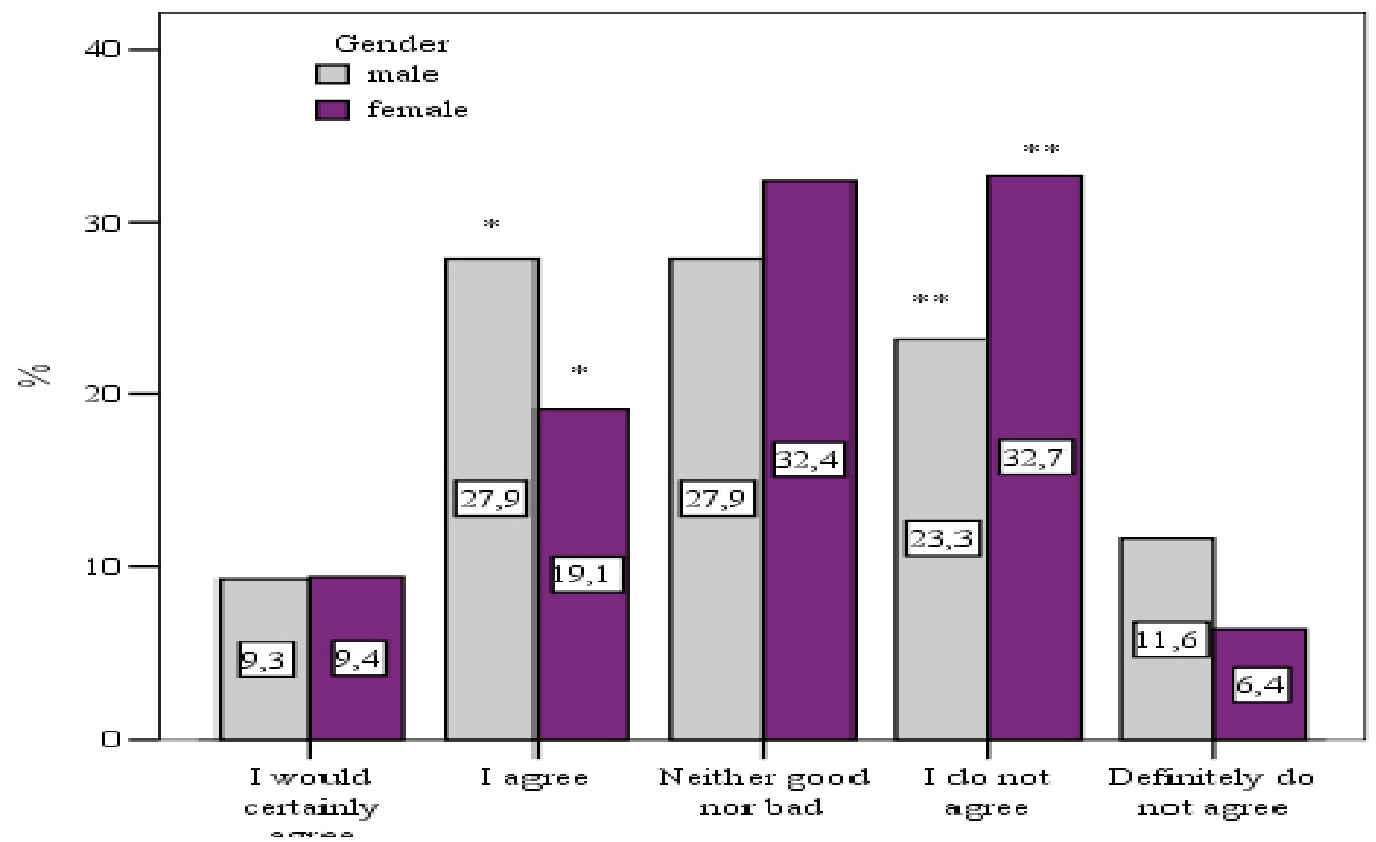

Figure 3 Response to the statement "I do not like when the teacher of physical education requires the fulfillment of the standards" distribution $(\%),\left(\chi^{2}(4)=10.23, p=0.037\right)$

Similarly, students do not like when the teacher uses offensive remarks (Fig. 4) (answers "completely agree" and "agree" were chosen relatively by 11.6 and $17.1 \%$ of males and 18.6 and $9.4 \%$ of females; $p=0.002$ ). Females and males answers differ significantly. 


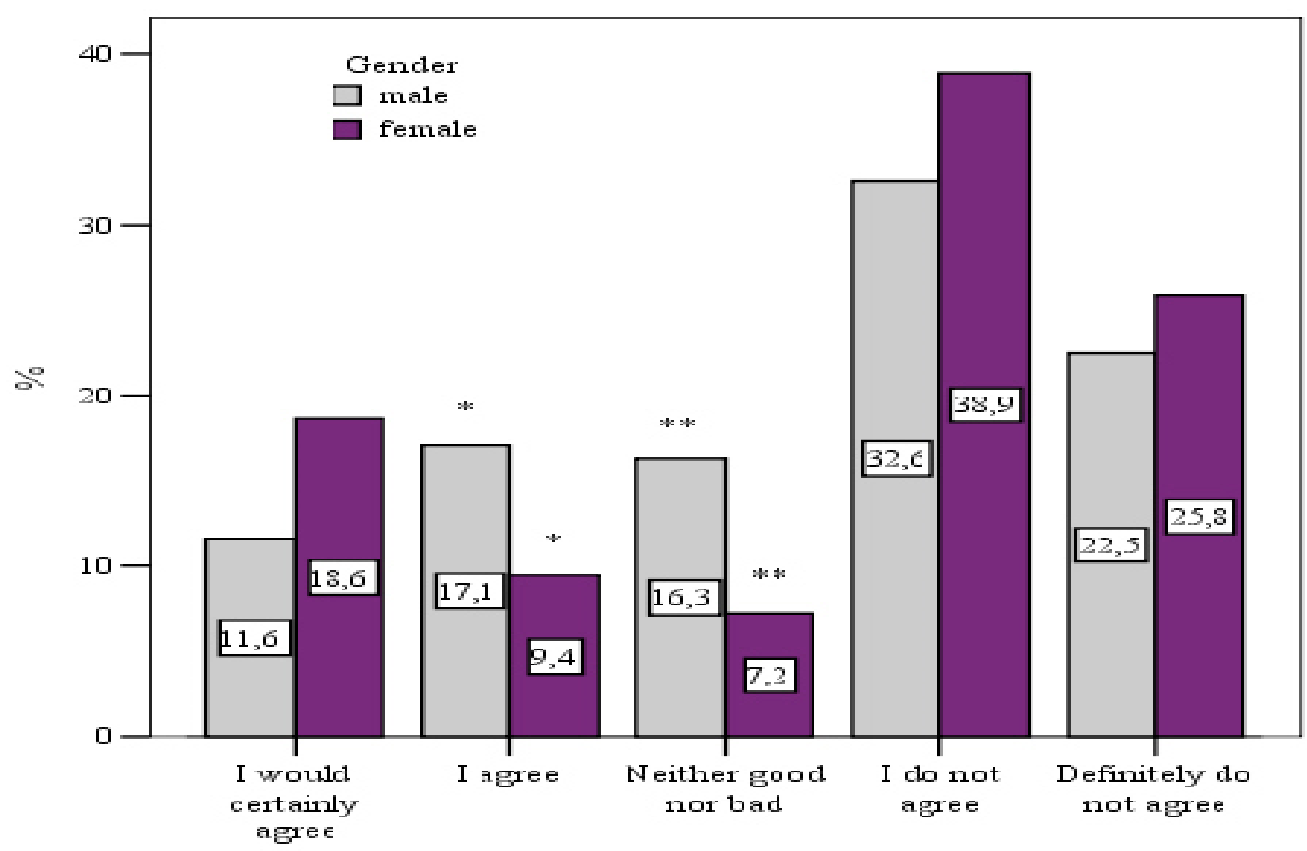

Figure 4 Response to the statement "I do not like when the teacher of physical education uses offensive remarks" distribution $(\%),\left(\chi^{2}(4)=17.12, p=0.002\right)$

Few students negatively evaluated the fact that the teacher of physical education does not participate in the activities, does not show enthusiasm, does not consider the students wishes, that physical education lectures are not interesting, though there is no significant statistical data difference observed $(p>0.05)$ according to the gender aspect.

\section{Discussion}

It is believed that students' learning shows their understanding about the educational environment and learning concepts. Moreover, the studies conducted had shown (Morkūnienè and Jucevičienè, 2010), that students who try to extend their knowledge, tend to adopt superficial learning methods and that the personal role in the learning-teaching process is perceived as passive. Usually their achievement level is lower in comparison with the students who try to understand and create the reality. Such an attitude is ascribed to the deep one, as students not only understand their role in the learning process but also actively participate in it. In our research case the students consider the studies at university as something very important, though for females it is much more important than for the males $(\mathrm{p}=0.001)$ and academic university requirements are evaluated relatively well (respectively $75.8 \%$ of males and $76.6 \%$ of females). The majority of respondents believe that their academic achievements are the same as the achievements of the others or even better. This shows serious and responsible attitude towards the studies.

The majority of the scientists indicate students' attitude towards the university studies, and the importance of the teacher (Pukelis and Pileičikiené, 2005; 
Savickienė, 2005; Luow, 2008; Balasooriya et al., 2009; El Hassan, 2009; Ellis et al., 2009, Pamuk and Thomson, 2009) stressing the fact that good academic results, teacher competences and the importance of the clear objectives are significant for the evaluating attitude (quoted from Bobrova et al., 2010). The results of the research had proved that the trait of the friendliness is the crucial for the physical education teacher while communicating with the students. According to P. Tamošauskas (2012) the personality of the student should not be considered as the object of educational performance and the activity must be organized in such a manner so that the innate powers could unfold. If the education is organized relying on these principles the psychological pressure and constraint are illuminated from the educational process. A partnership, democratic style of communication and the norms of human relationships are the most significant factors of the educational performance.

The understanding of the subject, good sense of humour and nice shape of the teacher of physical education are very important for the participants of the research. L. Bobrova et al., (2012), Neimane \& Rupeika (2012) in their researches revealed, that according to the students the most important things are: teacher's communicative skills, interesting content of the lectures and original representation of information. Introduction to the evaluating criteria and to the individual work tasks are also considered as ones of the most important advantages. L. Bobrova et al., (2012) research revealed that the teacher's responsibility for the quality of the subject develops positive students' attitude towards the studies.

Analyzing the research data about the most liked traits of the physical education teacher it came clear that students appreciate easy communication with the teacher, calm state of the teacher, taking into consideration students' opinion while giving the tasks, applying novelties and being creative. L. Bobrova's et al. (2012), Neimane \& Rupeika (2012) researches had shown, that students notice teacher's effort to discuss with them learning process, analyze their academic achievements, learning materials, students also agree with the individual work distribution, notice teacher's effort to motivate them.

The research conducted had revealed students' attitude towards learning in the high schools: more than the half of the participants (52.8\%) like to study, $43.8 \%$ do not like, $2.3 \%$ - do not like at all. The reasons are various: the usage of old teaching techniques, the speciality does not meet participant demands and the difficulties faced while studying. The participants identified such teaching quality factors: systemic information rendering, subjectivity, clarity, interest, theory relevance to the practical tasks, evaluating objectivity, adequacy to the subject, organization of the individual work, personal teacher's traits (Ratkevičienè, 2005; quoted from Bobrova et al., 2010).

Our research reviled students' attitude towards the disliked traits of the teachers. It has been found out that mostly students do not appreciate when the teacher requires the fulfilment of the standards and uses offensive remarks (relatively 
$65.9 \%$ of males and $56.5 \%$ of females; $p=0.002$ ). A significant part of the students negatively evaluate the fact that teachers do not participate in the physical activity, do not show enthusiasm and do not rely on students wishes, requests, moreover, lessons are not interesting. Relying on the questionnaire data (personal and other researches), P. Tamošauskas (2012) came clear, that a significant part of students are discontented with the physical education teacher's competence and their relationship with the students. Lithuanian Union of Students representatives (2009) had conducted a public opinion research and the results revealed that one third of the students think that teacher's behaviour is inadequate in respect to the student's health status. G. J. Rastauskiene et al. (2007) in her research claims that teachers should pay more attention to the information application and the novelty of information. The study conducted by A. G. Raišienè (2004) had shown that university teachers lack practical knowledge of different methods. While conducting the study a significant gap in the educational reform was reviled: the absence of the qualification improvement system for the university teachers. Qualification improvements for the teachers are left for themselves and the major knowledge development tool is self-education.

A university which relies on the contemporary educational paradigm, the organization of the study objective is becoming the integration and evaluation of the effective educational systems rather than the information rendering (Kirikova et al., 2013). If teachers at the contemporary high schools change the teaching paradigm they are considered to be undertakers of the educational process and founders of the educational environment. Hence, they are especially important to penetrate the major problems and project better learning process possibilities (Gudaitytè, 2001; quoted from Kirikova et al., 2013). The teacher is not only the provider of information, consultant or adviser but also the manager of students" "knowledge base" and supervisor-controller (Morkūnienè and Jucevičienè, 2010; Tandzegolskienè and Pileckaitè, 2012).

Nowadays work at university is becoming a big challenge for the teachers, as students, social partners, politicians and the society starts to question longcherished values of academic work (Bulotaite et al., 2012). A present-day teacher has to not only render the newest knowledge to the students but also conduct scientific researches and have management knowledge as it is stressed that part of the income universities must be earned individually (Šukys et al., 2006; Kardelis et al., 2007). Teachers usually lack motivation to create innovative learning environments as the expediency and values are doubtful, they lack creativeness or simply do not know what they do not know (Sefton, 1997; Šveikauskas, 2005; Beachey, 2007; Barman et al., 2007; Jurevičienè et al., 2010; quoted from Kirikova et al., 2013). Abilities of dealing with difficult situations largely depend upon one's individual predispositions, resistance to stress, way of assessing a situation and resulting type of action (RomanowskaTołłoczko, 2014). R. A. Zepp (2005) claims, that technologies can newly 
transform traditional role of the teacher; though some educational postmodernists claim that there will be a possibility to substitute teachers with the computers or some other technologies (quoted from Bulotaite et al., 2012). J. Jankauskas and N. Jatulienè (2008) state, that high schools too slowly free themselves from not so far away past stereotypes, students physical education relies on utilitarian-pragmatic tendency, the content of the training classes is oriented on the development of the physical peculiarities rather than on the inner personality parameter. Mentioned authors suggest improving the knowledge of the physical education students relying on three components: 1) world-view 2) anthropology 3) special physical education knowledge. According to the data provided by the authors less than the half of the participants positively evaluate the work and behaviour of physical education teachers (quoted from Norkus and Alūzas, 2012).

We think that for every high school physical education teacher is very important to know students' expectations and attempt to fulfil them, even more, positive communication and cooperation could help to achieve expected results.

\section{Conclusions}

Students ' attitude towards studies is serious and responsible: academic university requirements are evaluated as fairly high, studying at university is very important (though it is much more significant for the females).

Males and females stressed the fact that the most liked traits of physical education teacher are friendliness, good knowledge of the the subject, humor and nice shape, most disliked features are the requirements of the normative fullfilment as well as the usage of offensive remarks. Females and males answers differ significantly.

\section{References}

1. Baranauskienè, I., Bukauskienè, V., Valaikienė, A. (2011). Aukštojo mokslo studiju kokybès užtikrinimo vertinimas studentu požiūriu. Pedagogika, 102, 16-24.

2. Barkauskaitè, M., Nedzinskaitè, R. (2010). Edukologijos magistrantūros programu vadybos tobulinimas: studentu požiūris. Pedagogika, 99, 31-37.

3. Bitinas, B. (2000). Ugdymo filosofija: vadovelis aukštuju mokyklu studentams. Vilnius: enciklopedija, 248.

4. Bobrova, L., Grajauskas, L., Norkus, S. (2010). Kūno kultūros specialybès universitetiniu studiju kokybès vertinimas: studentu nuomone. Mokytojų ugdymas, $15(2), 162-176$.

5. Bobrova, L. (2012). Kūno kultūros ir sporto studiju programu studentu vertybiniu orientaciju sistemos raiška pagrindinèse gyvenimo srityse. Mokytojų ugdymas, 18(1), 82-101.

6. Bobrova, L., Grajauskas, L., Alūzas, R. (2012). Mokymo ir mokymosi kokybès įžvalgos: universitetiniu kūno kultūros studiju programos studentu vertinimo kontekstas. Studijos šiuolaikinèje visuomenėje. Mokslo darbai 3(1). Šiaurès Lietuvos kolegija. 30-36.

7. Bulotaite, L., Pociūtè, B., Bliumas, R. (2012). Universiteto dèstytoju pasitenkinimas darbu, darbo vertybès ir patiriamas darbe stresas. Acta Paedagogica Vilnensia, 28, 
$37-48$.

8. Corbin, J., Strauss, A. (2007). Basic of Qualitative Research: Techniques and Procedures for Developing Grounded Theory. 2 nd ad., Thousand Oaks: Stage.

9. Dadelo, S., Tamošauskas, P., Sakalys, V., Višinskienė, D. (2008). Vilniaus Gedimino technikos universiteto pirmo kurso studentu požiūrio $i$ kūno kultūra kaita per mokslo metus. Sporto mokslas, 4(54), 1-7.

10. Jackūnas, Ž. (1997). Demokratinio švietimo sklaida Lietuvoje. Švietimo reforma ir mokytojų rengimas, 4 tomas, Vilnius: VPU.

11. Kardelis, K., Šukys, S., Ušeckienè, L., Ališauskienė, R. (2007). Aukštujų universitetiniu mokyklu dèstytoju požiūrio $i$ institucijos veikla ir akademines vertybes raiška. Pedagogika, 87, 33-41.

12. Kirikova, L., Brunevičiūtè, R., Gudaitytè, D., Šveikauskas, V., Ramanauskas, I. (2013). Probleminio mokymosi proceso privalumai ir trūkumai: dèstytoju požiūris. Santalka, 21(1), 24-34.

13. Mackelo, O., Drūteikienè, G. (2010). Déstytojo ịvaizdis ir jo ịtaka studiju kokybei suvokti. Informacijos mokslai, 52, 68-83.

14. Morkūnienè, V., Jucevičienè, P. (2010). Studentu mokymosi, grịsto skirtinga edukacine paradigma, rezultatu vertinimo ypatumai. Ugdymas. Kūno kultūra. Sportas, 3(78), 5967.

15. Neimane, I., Rupeika, R. (2012). Student-centred learning in the Liepaja University. Society, integration, education. International Scientifical Conference, Rezekne: 369379.

16. Norkus, A., Alūzas, R. (2012). Studenty sveikatos ugdymas Lietuvos aukštosiose mokyklose: galimybès ir problemos. Studijos šiuolaikinèje visuomeneje. Mokslo darbai 3(1). Šiaurès Lietuvos kolegija. 185-12.

17. Palionyte, J., Pruskus, V. (2010). Sveika gyvensena jaunimo vertybiniu prioritetu kontekste (VPU studentu atvejis). Śiuolaikinè mokykla: jaunimo savijauta, prioritetai ir nuostatos. Vilnius: VPU 1-kla, 5, 75-102.

18. Poteliūnienè, S. (2010). Studentu fizini ugdyma ir sportininku rengima skatinantys veiksniai. Vilnius: VPU.

19. Pranckevičienè, A., Žąsytytè, E., Gustainienè, L. (2008). Studentu dvasingumo ir sveikatingumo sąajos. International journal of psychology: a biopsychosocial approach, 2, 9-28.

20. Raišienè, A. G. (2004). Studentu ir dèstytoju požiūrio ì aukštuju mokyklu dèstytoju edukacinę kompetencija raiška. Pedagogika, 70, 169-174.

21. Rastauskienè, G. J., Šeščilienè, I. M., Tilindienè, I. (2007). Studentu nuomonès apie studiju dalyku déstymo kokybe tyrimo duomenu vertinimo metodologinis pagrindimas. Ugdymas. Kūno kultūra. Sportas, 2 (65), 56-63.

22. Romanowska-Tołłoczko, A. (2014). Stressful situation in teaching profession - causes and consequenses. Pedagogics, psychology, medical-biological problems of physical training and sports, 2, 72-75.

23. Sirtautienè, D. (2006). Studiju universitete kokybès vertinimo aspektai: studentu požiūrio tyrimas. Pedagogika, 83, 117-121.

24. Šukys, S., Kardelis, K., Skurvydas, A. (2006). LKKA destytoju vertybiniu orientaciju ir požiūrio i akademija raiška aukštojo mokslo santykiu su visuomene raidos kontekste. Ugdymas. Kūno kultūra. Sportas, 1(60), 63-71.

25. Tamošauskas, P. (2007). Küno kultūros raidos tendencijos Lietuvos universitetinèse aukštosiose mokyklose. Santalka, 15 (2), 80-87.

26. Tamošauskas, P. (2012). Studentu fizinio ugdymo kaitos pedagoginiai ir psichologiniai ypatumai. Sporto mokslas, 1(67), 2-8. 
Proceeding of the International Scientifical Conference May $23^{\text {th }}-24^{\text {th }}, 2014$ Volume III

27. Tandzegolskienè, I., Pileckaite, R. (2012). Socialiniu mokslu srities studentu savarankiškos veiklos raiška universitetinèse studijose. Pedagogika, 97, 43-49.

28. Zulumskyte, A., Gelminaite, L. (2011). Studentu mokymosi Lietuvos universitetuose pobüdis. Tiltai, 2, 1-17.

29. Трухачёв, В.И., Тарасова, С.И., Таранова, Е.В., Скрипкин, В.С. (2014). Система здоровьесберегающего сопровождения педагогического процесса в современном вузе. Физическая культура: воспитание, образование, тренировка, 1, 2-6.

$\begin{array}{ll}\text { Jurgita Čepelionienė } & \text { Mykolas Romeris University, Vilnius Lithuanian Sports } \\ & \text { University, Kaunas } \\ & \text { E-mail: j.cepelioniene@gmail.com; } \\ & \text { Lithuanian Sports University, Kaunas } \\ \text { Vida Ivaškienė } & \text { E-mail: vida.ivaskiene@lsu.lt }\end{array}$

